\title{
Reinfection with SARS-CoV-2 after I52 Days: A Case Report
}

\author{
SM Abdullah Al Mamun'1, Quazi Tarikul Islam², Sanaullah Sarker ${ }^{3}$, Asifur Rahman ${ }^{4}$
}

\begin{abstract}
Background: In general, reinfection means a person was infected (got sick) once, recovered, and then later became infected again. Based on what we know from similar viruses, some reinfections are expected. We are still learning more about COVID-19. Ongoing COVID-19 studies will help us to understand.The degree of protective immunity conferred by infection with severe acute respiratory syndrome coronavirus 2 (SARS-CoV-2) is currently unknown. As such, the possibility of reinfection with SARS-CoV-2 is not well understood. Here we describe presentation and investigations of two instances of SARS-CoV-2 infection in the same individual.

Methodology : A 38-year-old man who is a resident of Dhaka city, Engineer by profession presented to doctors on two occasions with symptoms of viral infection. First time at a community testing event in June, 2020, and a second time to Evercare hospital at the mid November, 2020. Nasopharyngeal swabs were obtained from the patient at each presentation and twice during follow-up. RT PCR testing was done to confirm SARS-CoV-2 infection. CXR PIA view was performed in I $^{\text {st }}$ time of Covid infection \& HRCT of chest was performed during his stay at Evercare hospitals

Findings: The patient had two positive tests for SARS-CoV-2, the first on June 20th, 2020, and the second on November $18^{\text {th }}$ 2020, separated by two negative tests done during follow-up in July, 2020. The second infection was symptomatically more severe than the first with remarkable radiological changes of Chest in high resolution CT scanning .

Interpretation: Two subsequent negative RT PCR after $I^{\text {st }}$ positive with clinically asymptomatic period after 2 weeks of mild symptoms was observed in our patient. About 5 months later he was Covid I 9 positive again with moderate symptoms. These findings suggest that the patient was infected by SARS-CoV2 on two separate occasions probably by genetically distinct virus. Thus, previous exposure to SARS-CoV2 might not guarantee total immunity in all cases. All individuals, whether previously diagnosed with COVID19 or not, should take identical precautions to avoid infection with SARS-CoV-2. The implications of reinfections could be relevant for vaccine development and application.
\end{abstract}

Key words: COVID-19, Reinfection ,RT-PCR

(c) (i) (2) (2)

C.

DOI: https://doi.org//0.3329/jom.v22il.5/399

Copyright: ( 2021 Mamun SMA. This is an open access article published under the Creative Commons Attribution-NonCommercial-NoDerivatives 4.0 International License, which permits use, distribution and reproduction in any medium, provided the original work is properly cited, is not changed in any way and it is not used for commercial purposes.

Received: I 3 December, 2020;

Accepted: 28 December, 2020

\section{Introduction}

Infection with severe acute respiratory syndrome coronavirus 2 (SARS-CoV-2) leads to a detectable immune response, but the susceptibility of previously infected individuals to reinfection with SARS-CoV-2 is not well understood. SARS-

1. Senior Consultant \& coordinator of Respiratory Medicine, Evercare Hospitals, Dhaka

2. Professor of Medicine, Popular Medical College, Dhaka

3. Specialist Respiratory Medicine, Sheikh Fazilatunnesa Mujib Memorial KPJ specialized hospital 4.Registrar, Critical Care Medicine, Evercare Hospitals, Dhaka

Corresponding author: Dr. SM Abdullah Al Mamun, Senior Consultant \& coordinator of Respiratory Medicine, Evercare Hospitals, Dhaka e-mail: mamundr69@gmail.com
CoV-2 infection results in generation of neutralizing antibodies in patients. ${ }^{1}$ However, the degree to which this immune response indicates a protective immunity to subsequent infection with SARS-CoV-2 has not yet been elucidated.Reports of secondary infection events with SARSCoV-2 have been published from Hong Kong ${ }^{2}$ the Netherlands ${ }^{3}$ and Belgium ${ }^{4}$ and Ecuador ${ }^{5}$.

We present a case report of an individual who had two distinct COVID-19 illnesses on 5 months apart with more severity on $2^{\text {nd }}$ episode.

\section{Case history}

We present a case report of a 38-year-old male patient who was a resident of Dhaka City. The patient presented to a 
Table 1 : Time line of symptom onset, molecular diagnosis .

\begin{tabular}{|l|l|l|l|l|l|l|l|}
\hline $\begin{array}{l}\text { Symptom } \\
\text { onset }\end{array}$ & $\begin{array}{l}\text { Positive } \\
\text { real time } \\
\text { RT-PCR }\end{array}$ & $\begin{array}{l}\text { Symptom } \\
\text { resolution }\end{array}$ & $\begin{array}{l}\text { Negative } \\
\text { real time } \\
\text { RT-PCR }\end{array}$ & $\begin{array}{l}\text { Negative } \\
\text { real time } \\
\text { RT-PCR }\end{array}$ & $\begin{array}{l}\text { Symptom } \\
\text { onset for } \\
2^{\text {nd }} \text { time }\end{array}$ & $\begin{array}{l}\text { Positive } \\
\text { real time } \\
\text { RT-PCR }\end{array}$ & $\begin{array}{l}\text { Positive } \\
\text { real time } \\
\text { RT-PCR }\end{array}$ \\
\hline June $15^{\text {th }}$ & June $18^{\text {th }}$ & June $29^{\text {th }}$ & $6^{\text {th }}$ July & $16^{\text {th }}$ July & $\begin{array}{l}15^{\text {th }} \\
\text { November }\end{array}$ & $\begin{array}{l}18^{\text {th }} \\
\text { November }\end{array}$ & $\begin{array}{l}6^{\text {th }} \\
\text { December }\end{array}$ \\
\hline
\end{tabular}

community testing event held by the IEDCR on June20, 2020 \& was tested positive for COVID-19. He had symptoms consistent with viral infection (sore throat, cough, headache, nausea) which had started on June 15, 2020 (figure 1). The patient had no history of clinically significant underlying conditions, and no indications of compromised immunity were identified. During isolation at home, the patient's symptoms resolved (reported on June 29, 2020) and he continued to feel well . His repeat Nasopharyngeal sample tested negative on two occasion 7 days apart. Until November15, 2020 he was alright $\&$ full active .He performed many field activities as his official assignment \& lastly he stayed at home for 5 days. From where he developed symptoms. On November17, 2020, the patient sought care at ED of Evercare hospitals Dhaka with self-reported fever, headache, dizziness, cough, nausea for 2 days, at which time chest radiography was done and shows bilateral peripheral GGO with altered lab parameter ( CRP, D-dimer, LDH, Ferritin, CBC) \& he was admitted in Grey Zone of Evercare Hospitals according to Hospitals protocol . Next morning his Nasopharyngeal swab had been sent for SARS COV-2 Rt PCR \& after 3 hours report obtained. He was Positive for COVID-19. As the patient complaining shortness of breathing and $\mathrm{SpO} 2$ had been shown lower side $(<94 \%)$ in room air, supplemental O2 was started . Subsequently HRCT of Chest was performed and shows diffuse involvement of both lung .

Procedures Specimens were obtained from the patient by nasopharyngeal swab at the community testing event in $1^{\text {st }}$ time, when the result was positive for RT-PCR \& subsequent two sample during the period of isolation and recovery. Swabs were transported to the respective
Laboratory on cold packs and stored by refrigeration (4$8^{\circ} \mathrm{C}$ ) before real-time RT-PCR. Others Lab including CRP, D-dimer, LDH, Ferritin \& CXR P/A view done to know the course of COVID-19 disease .

During the $2^{\text {nd }}$ episode of disease, when the patient had been admitted to our hospitals for progressive worsening of symptoms, nasopharyngeal swab was collected from bedside by our trained technician \& transported to the our laboratory on cold packs and stored by refrigeration $\left(4-8^{\circ} \mathrm{C}\right)$ before real-time RT-PCR as before . Subsequent sample during the period of admission was sent to the PCR Lab maintaining cold packs . Lab test including CRP, D-dimer, LDH, Ferritin $\&$ HRCT of chest view done to know the course of COVID19 disease .

\section{Results}

The first nasopharyngeal swab, obtained at the community screening event on April 18, 2020, was positive for SARSCoV-2 on real-time RT-PCR testing. Two subsequent nucleic acid amplification tests obtained after resolution of symptoms were negative for SARS-CoV-2 RNA (table 1). The patient's symptoms returned on November 15, 2020 from community contact and he was admitted to hospital on November 17, 2020, at which time a Nasopharyngeal swab was obtained and was positive for SARS-CoV-2 infection by real-time RT-PCR testing. The patient required ongoing oxygen support in hospital and reported symptoms that included myalgia, cough, and shortness of breath. Chest radiography showed development of patchy, bilateral, interstitial opacities suggestive of viral or atypical pneumonia. With two episodes of symptoms consistent with COVID-19, and two specimens positive for SARS-CoV-2 separated by a period of 152 days

Table-II: Summary of laboratory results

\begin{tabular}{|l|l|l|l|l|l|l|l|}
\hline \multicolumn{4}{|c|}{$1^{\text {st }}$ Episode } & \multicolumn{5}{|c|}{$2^{\text {nd }}$ Episode } \\
\hline $\begin{array}{l}\text { Test } \\
\text { Methodology }\end{array}$ & $\begin{array}{l}\text { Real time } \\
\text { RT-PCR }\end{array}$ & $\begin{array}{l}\text { HRCT of } \\
\text { Chest }\end{array}$ & $\begin{array}{l}\text { Real time RT- } \\
\text { PCR after 2 } \\
\text { weeks }\end{array}$ & $\begin{array}{l}\text { Real time } \\
\text { RT-PCR }\end{array}$ & $\begin{array}{l}\text { HRCT of } \\
\text { Chest }\end{array}$ & $\begin{array}{l}\text { Real time RT- } \\
\text { PCR after 2 } \\
\text { weeks }\end{array}$ & $\begin{array}{l}\text { Real time } \\
\text { RT-PCR } \\
\text { after } \\
\text { weeks }\end{array}$ \\
\hline $\begin{array}{l}\text { Test } \\
\text { Result }\end{array}$ & Positive & $\begin{array}{l}\text { Peripheral } \\
\text { GGO }\end{array}$ & Negative & Positive & $\begin{array}{l}\text { Diffuse } \\
\text { GGO }\end{array}$ & Positive & Positive \\
\hline
\end{tabular}




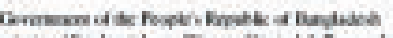

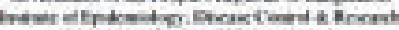

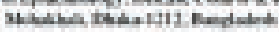

\section{Laboratory Test Report}

\begin{tabular}{|c|c|}
\hline 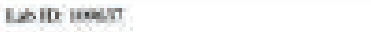 & Dex: Sin 30 \\
\hline 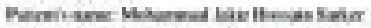 & Sos vta \\
\hline 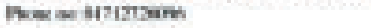 & Ened : erimpinofoud sen \\
\hline Adhe- Venen Etsia & 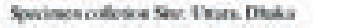 \\
\hline 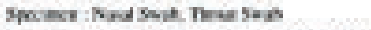 & 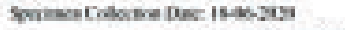 \\
\hline 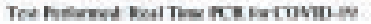 & Notred Bv each \\
\hline
\end{tabular}

\section{Result}

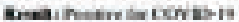

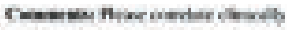
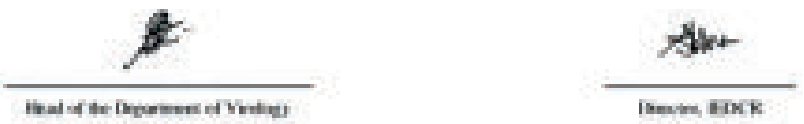

Figure 1 : Report of Nasopharyngeal swab for COVID-19 on $18 / 06 / 2020$

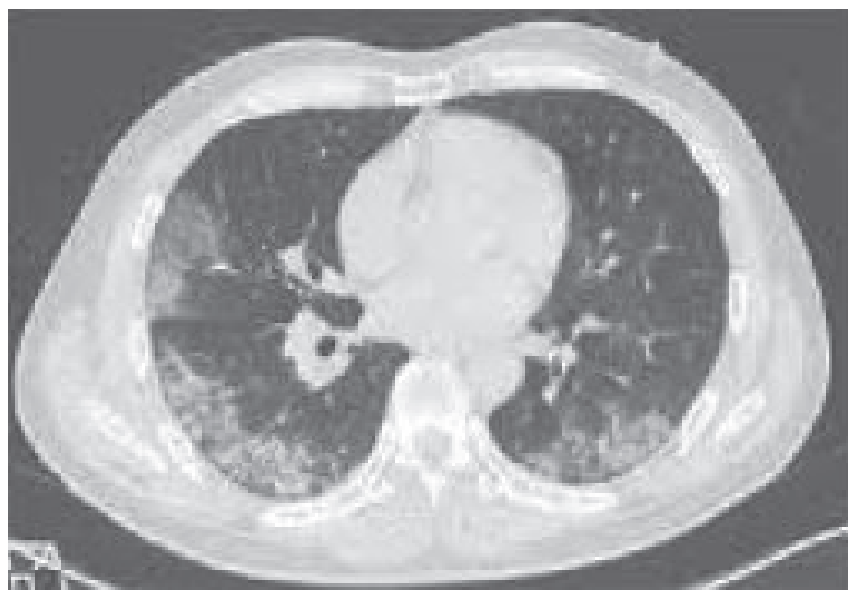

Figure 4: HRCT of patient on 18/11/2020

\section{Discussion :}

Our case report presents details of the individual in Bangladesh to have symptomatic reinfection with SARSCoV-2 after 152 days of first Infection. Similar to observations with the reinfection case in Ecuador ${ }^{6}$, our patient showed increased symptom severity in their second infection, whereas the cases from Belgium and the Netherlands ${ }^{7}$ and Hong Kong ${ }^{8}$ did not show a difference in severity of symptoms. The mechanisms that could account

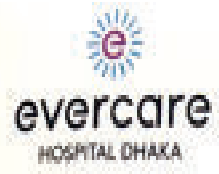

TNVTSTIGATION REPORT

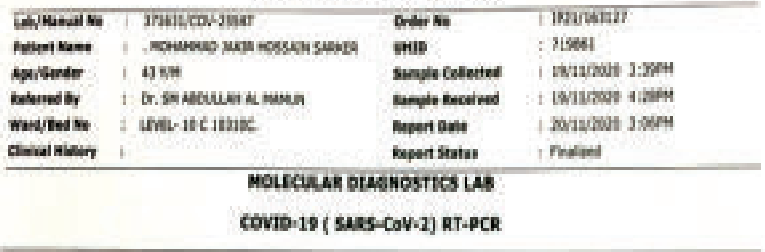

Type of aaghe: Nesophaynged isib

Ter Resalk:

COVID-19 (SAUS-COV-2)RKA : DETECTED

Atenul hierpretarion

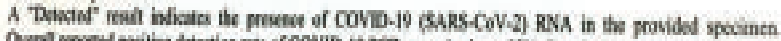

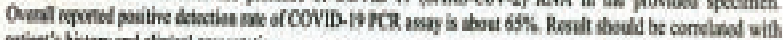
pulten's tisiany and clnical presanation.

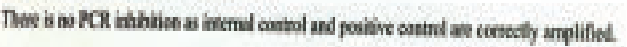

Uiali or Etectiat:

The linit of dowction of this bit ia 200 cogiesinL.

Figure 3: Report of Nasopharyngeal swab for COVID-19 on $18 / 11 / 2020$

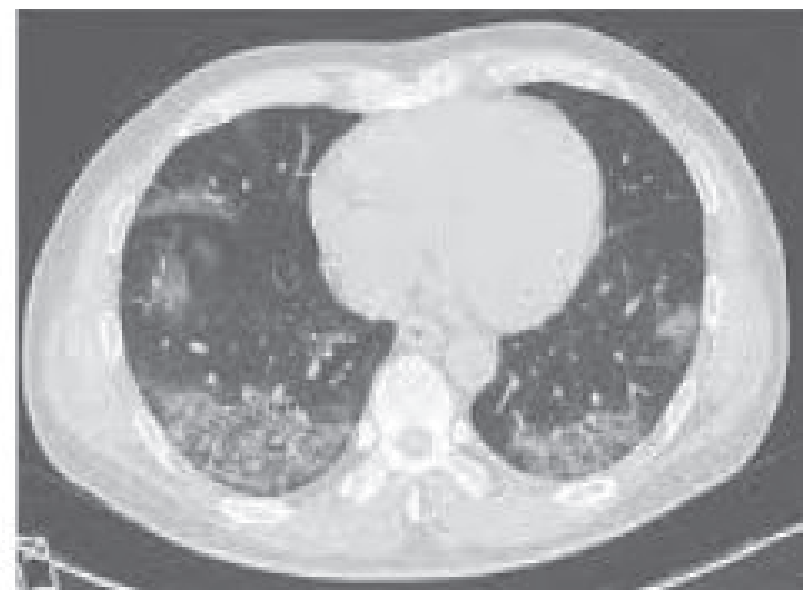

for a more severe secondary infection can only be speculated. First, a very high dose of virus might have led to the second instance of infection and induced more severe disease. ${ }^{9}$ Second, it is possible that reinfection was caused by a version of the virus that was more virulent, or more virulent in this patient's context. Third, a mechanism of antibody dependent enhancement might be the cause, a means by which specific Fc-bearing immune cells become infected with virus by binding to specific antibodies. This mechanism has been seen 
previously with the beta coronavirus causing severe acute respiratory syndrome. ${ }^{10}$ In that case, the patient recovered and was discharged from hospital.

The individual associated with these two SARS-CoV-2 infections had no immunological disorders that may influence reinfection. He was not taking any immunosuppressive drugs. The individual was negative for HIV by antibody and RNA testing (data not shown) and had no obvious cell count abnormalities.

It is possible that we have reported a case of continuous infection entailing deactivation and reactivation. However, for such a hypothesis to be true, a mutational rate of SARS$\mathrm{CoV}-2$ would be required that has not yet been recorded. ${ }^{11,12}$ Limitation in our case was genome sequence was not possible.

Our findings have implications for the role of vaccination in response to COVID-19. If we have truly reported a case of reinfection, initial exposure to SARS-CoV-2 might not result in a level of immunity that is $100 \%$ protective for all individuals. With respect to vaccination, this understanding is established, with influenza regularly showing the challenges of effective vaccine design. ${ }^{13}$ A major limitation of our case study is that we were unable to undertake any assessment of the immune response to the first episode of SARS-CoV-2.

Conclusion: Re infection in COVID-19 is not a new issue now. One should keep eye on second infection where the features may be worse than first attack.

\section{References :}

1. Ju B, Zhang Q, Ge J, et al. Human neutralizing antibodies elicited by SARS-CoV-2 infection. Nature 2020; 584: 11519.

2. Callow KA, Parry HF, Sergeant M, Tyrrell DA. The time course of the immune response to experimental coronavirus infection of man. Epidemiol Infect 1990; 105: 435-46.

3. Chang S-C, Wang J-T, Huang L-M, et al. Longitudinal analysis of severe acute respiratory syndrome (SARS) coronavirus-specific antibody in SARS patients. Clin Diagn Lab Immunol 2005; 12: 1455-57.

4. Huang AT, Garcia-Carreras B, Hitchings MDT, et al. A systematic review of antibody mediated immunity to coronaviruses: antibody kinetics, correlates of protection, and association of antibody responses with severity of disease. medRxiv 2020

5. Liu W, Fontanet A, Zhang P-H, et al. Two-year prospective study of the humoral immune response of patients with severe acute respiratory syndrome. J Infect Dis 2006; 193: 79295.

6. Prado-Vivar B, Becerra-Wong M, Guadalupe JJ, et al. COVID-19 re-infection by a phylogenetically distinct SARSCoV-2 variant, first confirmed event in South America. SSRN 2020;

7. Van Elslande J, Vermeersch P, Vandervoort K, et al. Symptomatic SARS-CoV-2 reinfection by a phylogenetically distinct strain. Clin Infect Dis 2020

8. To KK-W, Hung IF-N, Ip JD, et al. COVID-19 re-infection by a phylogenetically distinct SARS-coronavirus-2 strain confirmed by whole genome sequencing. Clin Infect Dis 2020;

9. Guallar MP, Meiriño R, Donat-Vargas C, Corral O, Jouvé $\mathrm{N}$, Soriano V. Inoculum at the time of SARS-CoV-2 exposure and risk of disease severity. Int J Infect Dis 2020; 97: 290 92

10. Yip MS, Leung NH, Cheung CY, et al. Antibody-dependent infection of human macrophages by severe acute respiratory syndrome coronavirus. Virol J 2014; 11: 8211.

11. Hill V, Rambaut A. Phylogenetic analysis of SARS-CoV-2 genomes. March 6, 2020. https://virological.org/t/ phylodynamic-analysis-ofsars-cov-2-update-2020-03-06/ 420

12. Mercatelli D, Giorgi FM. Geographic and genomic distribution of SARS-CoV-2 mutations. Front Microbiol 2020; 11: 1800

13. Osterholm MT, Kelley NS, Sommer A, Belongia EA. Efficacy and effectiveness of influenza vaccines: a systematic review and meta-analysis. Lancet Infect Dis 2012; 12: 3644. 